\title{
Regras de fuga: quatro poemas
}

Eleazar Venancio Carriasi

\section{Sobre os instantes solares}

Você deve ter percebido, se já foi dos que acordam cedo: cada manhã tem seu ritmo.

$\mathrm{O}$ que quero dizer com isso é que gosto muito das séries: equilibram, não existindo.

O que se não há concebido assim se explica nos dedos: fora, razão; tato, no íntimo.

O que quero dizer com isso diria melhor quem planta milho: cadência lunar: promessa e medo.

Como, diante de mim, o círculo grávido de sangue, subindo: sem tirar do lugar, movê-lo.

O que quero dizer com isso você já deve ter percebido: se ali te vejo, aqui me excedo. 


\section{Didática}

É uma aprendizagem lenta e difícil

a solidão.

Exige uma técnica

que não se aprende

nos bares,

que não se aprende

no mar.

Aprende-se com o fraquejar

dos melhores amigos,

mas sobretudo se aprende

na multidão.

É uma aprendizagem lenta e difícil

a solidão. 


\section{Mito}

$::$

Todas as coisas sólidas

vibram ao som do teu nome

És um deus arremessado

contra as vigas de meu mundo

/I 


\section{Fuga}

$E$, se resta alguma estima,

acima de tudo, promete: não voltarás.

Vai. É um risco cada esquina,

mas, corre as ruas como se fossem iguais.

Que elas não são. Não liga.

Eu te daria meu alforje.

Mas vê. Não há nada nele que consiga

tornar teu passo mais forte.

Não contes com asas - nem digas

que não te basta o ritmo incisivo.

Não, não te despeças. Não precisa.

Levas nos calcanhares

meu coração pervasivo.

\footnotetext{
'Eleazar Venancio Carrias nasceu em 1977, num sítio no interior da Pará. Publicou Quatro Gavetas (2009), vencedor do Prêmio Dalcídio Jurandir de Literatura 2008 na categoria poesia. Regras de Fuga, sua segunda coletânea de poemas, saiu em 2017, pela e-galáxia. Mestre em educação pela Universidade de Brasília, atua como pedagogo no Instituto Federal do Pará - Campus Tucuruí.
} 